\title{
ОПТИМІЗАЦІЯ РІВНЯ ПЕРЕСТРАХУВАЛЬНОГО ЗАХИСТУ СТРАХОВИКА НА ПРИКЛАДІ ДІЯЛЬНОСТІ ПРАТ «УАСК АСКА»
}

\section{OPTIMIZATION OF THE LEVEL OF INSURANCE REINSURANCE PROTECTION ON THE EXAMPLE OF ACTIVITY PRJSC «UJSIC ASKA»}

\author{
Хома Ірина Борисівна \\ доктор економічних наук, професор, \\ Національний університет «Львівська політехніка» \\ ORCID https://orsid.org/0000-0002-3737-1601 \\ Khoma Iryna \\ Lviv Polytechnic National University
}

\begin{abstract}
У статті розглянуто аналіз страхової діяльності ПрАТ «УАСК АСКА» в аспекті проведення перестрахувального захисту і визначення його оптимального рівня на основі використаної інтегрованої економіко-математичної моделі. Перестрахування у страховій діяльності на ринку є різновидом страхування. Основними напрямками діяльності досліджуваної страхової компанії $€$ надання страхових послуг та послуг, пов'язаних зі страхуванням. Актуальність статті полягає у фрормуванні системного підходу щодо побудови есрективного механізму оцінювання перестрахувального захисту страховика в розрізі детального попереднього аналізу фрінансового стану компанії, зокрема через оцінку стану страхового порторелю, валових та чистих страхових премій, а також страхових премій переданих у перестрахування ПрАТ «УАСК АСКА», запасу платоспроможності та впливу усіх ризиків страхування на операцію перестрахування з метою точного обчислення оптимального рівня перестрахувального захисту на звітну дату. Досліджено негативні та позитивні чинники, які впливають на страхову компанію, та виявлено, що видам страхування, які залишаються на утримані страховика, притаманна значна непропорційність у розподілі, що коригує оптимальність рівня перестрахувального захисту.

Ключові слова: страхова діяльність, перестрахувальний захист, рівень перестрахування, оптимізація.
\end{abstract}

В статье проведён анализ страховой деятельности ПрАО «УАСК АСКА» в аспекте перестраховочной защиты и определён его оптимальный уровень на основе использованной интегрированной экономико-математической модели. Перестрахование в страховой деятельности на рынке является одним из видов страхования. Основными направлениями деятельности исследованной страховой компании есть предоставление страховых услуг и услуг, связанных со страхованием. Актуальность статьи состоит в формировании системного подхода относительно построения эффективного механизма оценивания перестраховочной защиты страховика в разрезе детального предварительного анализа фринансового состояния компании, в частности через оценку состояния страхового портоеля, валовых и чистых страховых премий, а также страховых премий переданных в перестрахование ПрАТ «УАСК АСКА», запаса платеспособности и влияния всех рисков страхования на операцию перестрахования с целью точного расчёта оптимального уровня перестраховочной защиты на отчётную дату. Исследованы отрицательные и положительные факторы, которые влияют на страховую компанию, и выявлено, что видам страхования, которые остаются на удержание страховика, свойственна значительная непропорциональность в распределении, что корректирует оптимальность уровня перестраховочной защиты.

Ключевые слова: страховая деятельность, перестраховочная защита, уровень перестрахования, оптимизация.

The analysis of insurance activity of PrJSC «UJSIC ASKA» is considered in the article in the aspect of reinsurance protection and determination of its optimal level on the basis of the used integrated economic-mathematical model. Reinsurance in insurance activities on the market is a type of insurance. The main activities of the researched insurance company are the provision of insurance and insurance-related services. The purpose of this article is to study the elements of the insurance company's strategy in the market through the formation of an integrated mechanism for assessing reinsurance protection through the calculation of its optimal level on the example of PrJSC 
«UJSIC ASKA». The actuality of the article is to form a systematic approach to building an effective mechanism for assessing the reinsurance protection of the insurer in terms of detailed preliminary analysis of the company's financial condition, in particular through assessing the insurance portfolio, gross and net insurance premiums, and insurance premiums transferred to reinsurance PrJSC «UJSIC ASKA», the company's solvency margin and the impact of all insurance risks on the reinsurance operation in order to accurately calculate the optimal level of reinsurance protection at the reporting date. Negative and positive factors that affect the insurance company have been studied and it has been found that the types of insurance that remain on the insurer's retention are characterized by a significant disproportion in the distribution, which adjusts the optimal level of reinsurance protection. Methods of analysis and synthesis, research method, optimization method in the system of economic and mathematical modeling are used. To implement this integrated model, the MS Excel program "Solution Search" was used. The results of the simulation on the example of the activities of PrJSC «UJSIC ASKA» revealed that the reduction of reinsured premiums will have a significant impact on other indicators of the company. This will lead to an increase in net premiums and, consequently, an increase in the risks that will remain on the insurer's maintenance. The result will be an increase in net losses on insurance premiums, and due to a decrease in reinsurance, the insurance company will receive lower commissions from reinsurers. It is assumed that the costs of running an insurance company should not change significantly. The insurer's investment income is expected to increase due to the increase in investment resources. As a result, the company will receive a significant pre-tax financial result, from which it will pay the highest income tax in recent years. To improve the financial results of the insurance company in the future it is recommended to reduce its reinsurance.

Keywords: insurance activity, reinsurance protection, reinsurance level, optimization.

Постановка проблеми. Як відомо, фрінансова система країни являє собою інтегровану сукупність взаємопов'язаних між собою сфрер та ланок фрінансових відносин, у процесі фрункціонування яких фрормуються, акумулюються і в подальшому розподіляються різноманітні фонди фрінансових ресурсів. Страховий ринок $€$ її невід'ємним складовим елементом. Функціонування його нерозривно пов'язано 3 ефективністю кожного 3 елементів даного ринку. Саме діяльність страхових компаній визначає вектор розвитку страхового ринку загалом. Окрім безпосередньо страхової діяльності страхові компанії відіграють важливу роль у розвитку економіки шляхом здійснення інвестиційної діяльності сприяючи різним її галузям. Тому ефективність діяльності страхових компаній $є$ важливою для функціонування економіки країни через періодичне оцінювання та удосконалення, зокрема, перестрахувального захисту страховика, якщо виникають ризикові страхові ситуації.

Аналіз останніх досліджень і публікацій. На сучасному етапі тенденції розвитку діяльності страхових компаній досліджувались у працях таких науковців, як: Івасів Б.С., Кнейслер О.В., Клапків Б.С., Олексин А.Г., Прокоф'єва О.В., Татаріна Т.В., Ткаченко К.В., Третяк Т.В., Шірінян Л.В. тощо. Кожен з цих авторів по різному підходив до проблем страхового ринку та моментів покращення страхової діяльності та підняття ефективності окремих страхових компаній, досліджуючи також і питання перестрахувального захисту страховиків.

Виділення невирішених раніше частин загальної проблеми. Оцінка страхової діяльності на даний момент залишається актуаль- ною та потребує постійного удосконалення, зокрема і в розрізі не тільки побудови ефективного інтегрованого механізму оцінювання перестрахувального захисту страховика в аспекті оптимального перенесення їх ризиків, але й точного обчислення оптимального рівня перестрахувального захисту. Так як діяльність окремих страхових компаній суттєво різниться, вони мають також і доволі різну, і не завжди стабільну фрінансову стійкість, яка у свою чергу попадає останніми роками і під вплив світової пандемії COVID-19. Тому важливим $€$ порівняльний аналіз оптимального рівня перестрахувального захисту на прикладі конкретних страхових компаній, зокрема у нашому випадку на прикладі діяльності Приватного акціонерного товариства «Українська акціонерна страхова компанія АСКА» (ПрАТ «УАСК АСКА»).

Формулювання цілей статті. Метою даної статті є дослідження елементів стратегії діяльності страхової компанії на ринку через орормування інтегрованого механізму оцінювання перестрахувального захисту через обчислення його оптимального рівня на прикладі діяльності ПрАТ «УАСК АСКА».

Виклад основного матеріалу дослідження. Як відомо, перестрахування у страховій діяльності на ринку $є$ різновидом страхування, що здійснюється одним страховиком, якого називають цедентом (перестрахувальником) на визначених договором умовах ризику виконання всіх або частини своїх обов'язків перед страхувальником у іншого страховика, тобто перестраховика. При здійсненні перестрахування кожна страхова компанія виходить 3 того, що даний 
процес повинен бути економічно ефективним при досягненні поставлених завдань, а також повинен враховувати вартість операції перестрахування. Сам процес перестрахування проводиться перестрахувальником з ціллю захисту себе від фрінансових втрат і особливо непередбачених, які він може понести в умовах підвищення ризику. Як правило, перестрахувальник - це сторона, що передає ризик при операції перестрахування, при цьому перестрахувальник - це або страховик, що прийняв на себе ризик за встановленим оригінальним договором страхування або співстрахування (страховому полісу) і передає його у перестрахування. Ретроцедент $\epsilon$ особою, що прийняв ризик на себе у процесі перестрахування і частково може передати його іншому перестраховику, якого називають ретроцесіонером [1].

Розглянемо процес перестрахування на прикладі ПрАТ «УАСК АСКА», провівши попередньо оцінку її фрінансового стану. Як відомо, ПрАТ «УАСК АСКА» $€$ першою недержавною страховою компанією, яка була заснована 20 червня 1990 року. Основними напрямками діяльності Компанії $\epsilon$ надання страхових послуг та послуг, пов'язаних зі страхуванням. Основними видами діяльності відповідно КВЕД є: 65.12 - інші види страхування, крім страхування життя; 65.20 - перестрахування; 66.21 - оцінювання ризиків та завданої шкоди [2]. ПрАТ «УАСК АСКА» у свою чергу є учасником банківської фрінансової групи ПАТ «ПУМБ» і входить до складу «Систем Кепітал Менеджмент», будучи однією з найпотужніших фрінансово-промислових груп України. ПрАТ «УАСК ACКА» має 31 регіональний підрозділ на території України. Компанія здійснює страхування на підставі ліцензій про ведення страхової діяльності, виданих Державною комісією 3 регулювання ринків фрінансових послуг України. ПрАТ «УАСК АСКА» має 35 ліцензій на здійснення добровільних і обов'язкових видів страхування [2].

Основними дослідженими негативними чинниками, які впливають на дану страхову компанію, є нестабільна ситуація в державі, зокрема викликана пандемією Covid-19, зниження загальної купівельної спроможності населення та часткова еміграція. До основних позитивних фракторів відноситься впровадження інновацій страхових продуктів, лояльна цінова політика та взаємодія 3 клієнтами. Оцінювання даного страховика виявило, що до його сильних сторін відноситься широка регіональна представленість, достатньо якісні страхові послуги, значна частка ринку, ефективність управління та кваліфрікація кадрів. Серед слабких сторін можна виділити погіршення фрінансової стійкості за останні роки, незначний обсяг реклами та досить велику частку перестрахування і недостатню увагу до корпоративного навчання працівників.

Оскільки, компанія займає хороші позиції на ринку, доцільно продовжувати здійснювати діяльність у даному векторі 3 акцентом на впровадження інноваційних рішень та індивідуальним підходом до кожного клієнта. Проведемо загальну оцінку стану та діяльності ПрАТ «УАСК АСКА», зокрема аналіз страхової діяльності компанії, а також ії фрінансового стану, та запропонуємо окремі рекомендації щодо проведення перестрахувального захисту даного страховика.

Як відомо на загальний фрінансовий стан і стан перестрахування ПрАТ «УАСК АСКА» впливає насамперед ії стан страхового портфрелю (рис. 1). Дана страхова компанія входить в топ-10 компаній за обсягом залучених страхових премій у 2020 році.

У табл. 1. систематизовано дані щодо обсягів валових і чистих страхових премій та виплат, а також розраховано рівень виплат для кожного з видів страхування та загальний рівень виплат.

У 2020 році страховик залучив більше 1 млрд. грн. страхових премій, при цьому основна їх частина припадала на страхування вогневих ризиків та ризиків стихійних явищ, страхування майна, страхування залізничного транспорту та відповідальності перед третіми особами. Рівень виплат компанії достатньо низький та складає 29,14\%. Аномально високими за рівнем виплат видами страхування у звітному році були медичне страхування, страхування майна та страхування наземного транспорту.

Після передачі ризиків на перестрахування відбулась суттєва зміна структури страхового порторелю. Наочно структуру валових та чистих страхових премій ПрАТ «УАСК АСКА» станом на 2020 рік представлено на рис. 1. та рис. 2.

3 рис. 1 та рис. 2 видно, що після здійснення операцій перестрахування найбільшу частку в порторелі займало страхування цивільної відповідальності власників транспортних засобів за внутрішніми та міжнародними договорами, страхування наземного транспорту та медичне страхування. При цьому рівень виплат за ризиками, що залишилися 


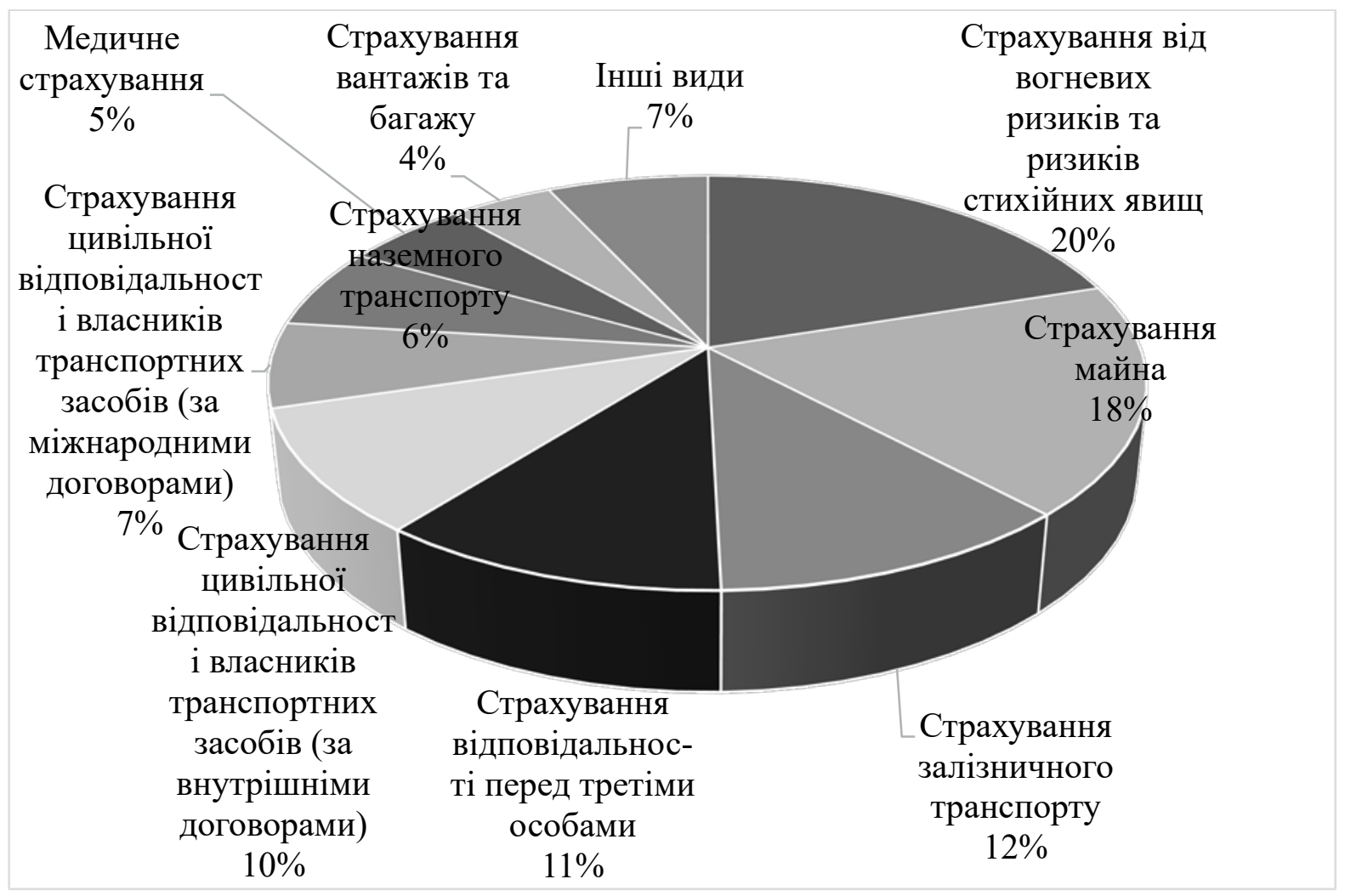

Рис. 1. Структура валових страхових премій за видами страхування ПрАТ «УАСК АСКА» за 2020 рік

Джерело: [2; 3]

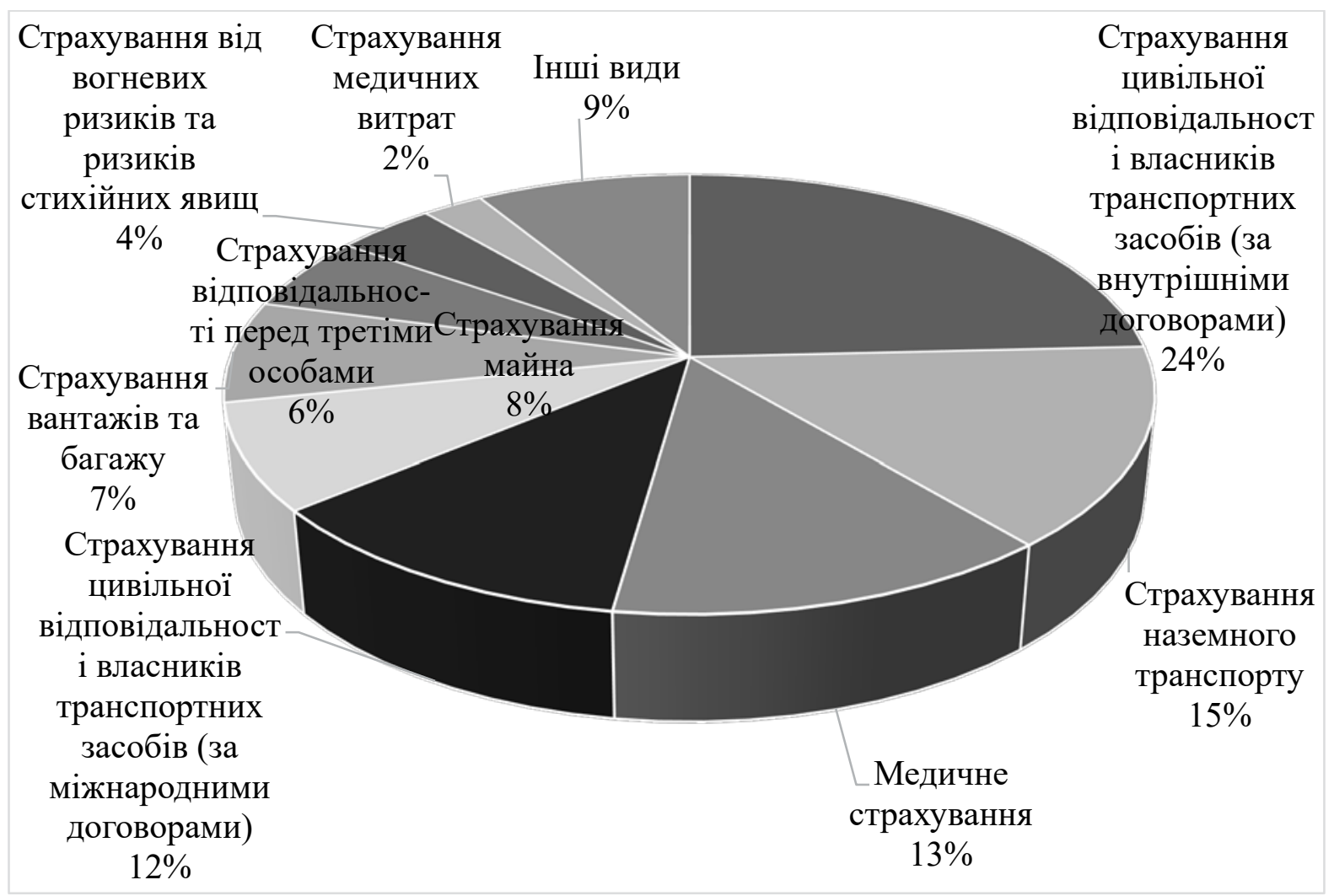

Рис. 2. Структура чистих страхових премій за видами страхування ПрАТ «УАСК АСКА» $3 а 2020$ рік

Джерело: [2; 3] 
Таблиця 1

Страховий портоель ПрАТ «УАСК АСКА» 322020 рік

\begin{tabular}{|c|c|c|c|c|c|c|}
\hline Види страхування & $\begin{array}{l}\text { Валові } \\
\text { премії, } \\
\text { тис. грн. }\end{array}$ & $\begin{array}{l}\text { Валові } \\
\text { виплати, } \\
\text { тис. грн. }\end{array}$ & $\begin{array}{c}\text { Рівень } \\
\text { виплат, } \\
\% \\
\end{array}$ & $\begin{array}{c}\text { Чисті } \\
\text { премії, } \\
\text { тис. грн. }\end{array}$ & \begin{tabular}{|c|} 
Чисті \\
виплати, \\
тис. грн. \\
\end{tabular} & $\begin{array}{c}\text { Рівень } \\
\text { виплат, } \\
\% \\
\end{array}$ \\
\hline $\begin{array}{l}\text { Страхування від вогневих } \\
\text { ризиків та ризиків стихійних } \\
\text { явищ }\end{array}$ & 201803 & 11033 & 5,47 & 15476 & 7775 & 50,24 \\
\hline Страхування майна & 182062 & 141000 & 77,45 & 29844 & 224 & 0,75 \\
\hline $\begin{array}{l}\text { Страхування залізничного } \\
\text { транспорту }\end{array}$ & 117510 & 1188 & 1,01 & 8224 & 56 & 0,68 \\
\hline $\begin{array}{l}\text { Страхування } \\
\text { відповідальності перед } \\
\text { третіми особами }\end{array}$ & 111594 & 126 & 0,11 & 21299 & 126 & 0,59 \\
\hline $\begin{array}{l}\text { Страхування цивільної } \\
\text { відповідальності власників } \\
\text { транспортних засобів } \\
\text { (за внутрішніми договорами) }\end{array}$ & 98136 & 26277 & 26,78 & 93006 & 26277 & 28,25 \\
\hline $\begin{array}{l}\text { Страхування цивільної } \\
\text { відповідальності власників } \\
\text { транспортних засобів (за } \\
\text { міжнародними договорами) }\end{array}$ & 66996 & 22931 & 34,23 & 44814 & 13212 & 29,48 \\
\hline $\begin{array}{l}\text { Страхування наземного } \\
\text { транспорту }\end{array}$ & 63188 & 41253 & 65,29 & 56248 & 39546 & 70,31 \\
\hline Медичне страхування & 53664 & 46792 & 87,19 & 51301 & 46792 & 91,21 \\
\hline $\begin{array}{l}\text { Страхування вантажів } \\
\text { та багажу }\end{array}$ & 45507 & 21 & 0,05 & 28756 & 21 & 0,07 \\
\hline Інші види & 70399 & 3946 & 5,61 & 34960 & 3946 & 11,29 \\
\hline Сума & 1010859 & 294567 & 29,14 & 383928 & 137975 & 35,94 \\
\hline
\end{tabular}

на утриманні страхової компанії складало 35,94\%. Найбільшими за рівнем виплат у даному випадку є саме медичне страхування, страхування наземного транспорту та страхування від вогневих ризиків та ризиків стихійних явищ, про що було зазначено раніше.

Для демонстрації розподілу між преміями та виплатами на рис. 3 представлено криву Лоренца.
3 рис. 3 видно, що видам страхування, які залишаються на утримані страховика, притаманна значна непропорційність у розподілі. Проте, не зважаючи на це, страховий порторель компанії можна назвати достатньо диверсифрікованим.

Проведемо локальну оцінку перестрахувального захисту ПрАТ «УАСК АСКА». Як виявили дослідження, хеджування ризиків

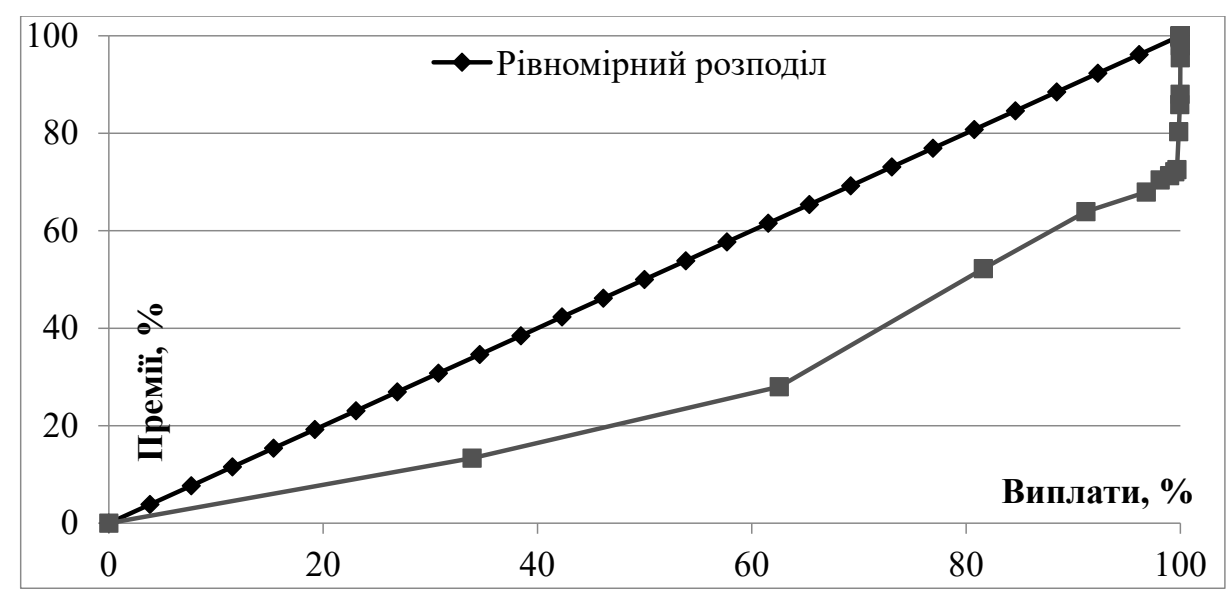

Рис. 3. Крива Лоренца 
слід проводити шляхом укладення сракультативних та облігаторних договорів перестрахування. Укладення договорів перестрахування здійснюється як безпосередньо зі страховими компаніями, так і з залученням посередників - страхових брокерів. Серед партнерів перестрахувального захисту ПрАТ «УАСК АСКА» $\epsilon$ перестрахувальні закордонні компанії та товариства, а саме: Hannover Reinsurance Company; SOVAG; SCOR Global P\&C (Франція); Swiss Reinsurance Company та АT «Польське перестрахувальне товариство». Серед партнерів компанії $\epsilon$ також страхові та перестрахові брокери міжнародного рівня: Представництво «АОН Лімітед»; Представництво «Вілліс Польска»; Представництво «Марш Юроп С.А.»; Представництво «Оукшотт Іншуренс Консалтантс Лімітед» (Ейріс).
Для оцінки страхового захисту компанії у табл. 2 представлено рівень перестрахування компанії та рівень перестрахування по ринку за період 2015-2020 рр.

3 табл. 2 видно, що рівень перестрахування по ринку коливається за аналізовані періоди, проте ці зміни не є надто великими. Що до рівня перестрахування, який є притаманний для компанії, то він суттєво перевищує рівень по ринку та зростає протягом аналізованих періодів. У табл. 3 представлено обсяги перестрахування страхових премій за видами страхування ПрАТ «УАСК АСКА» у 2020 році.

Як видно з табл. 3, дана страхова компанія за останні роки активно здійснювала перестрахування ризиків. Разом із зростанням обсягу премій у порівнянні з попереднім періодом відбулося збільшення рівня перестра-

Рівень перестрахування ПрАТ «УАСК АСКА»

Таблиця 2 та рівень перестрахування по ринку за 2015-2020 роки

\begin{tabular}{|l|c|c|c|c|c|c|}
\hline \multicolumn{1}{|c|}{ Показник } & \multicolumn{7}{c|}{ Роки } \\
\cline { 2 - 7 } & $\mathbf{2 0 1 5}$ & $\mathbf{2 0 1 6}$ & $\mathbf{2 0 1 7}$ & $\mathbf{2 0 1 8}$ & $\mathbf{2 0 1 9}$ & $\mathbf{2 0 2 0}$ \\
\hline Рівень перестрахування АСКА, \% & 46,66 & 59,46 & 75,57 & 71,06 & 62,15 & 62,76 \\
\hline Рівень перестрахування по ринку, \% & 30,51 & 36,25 & 33,33 & 36,02 & 42,21 & 36,34 \\
\hline
\end{tabular}

Джерело: [2; 3]

Таблиця 3

Валові страхові премії та страхові премії передані у перестрахування ПрАТ «УАСК АСКА» у 2020 році

\begin{tabular}{|l|c|c|c|c|}
\hline \multicolumn{1}{|c|}{ Види страхування } & \multicolumn{2}{|c|}{ Валові страхові премії } & \multicolumn{2}{c|}{$\begin{array}{c}\text { Страхові премії, } \\
\text { передані у } \\
\text { перестрахування }\end{array}$} \\
\cline { 2 - 5 } & $\begin{array}{c}\text { Обсяг, } \\
\text { тис. грн. }\end{array}$ & Частка, \% & $\begin{array}{c}\text { Обсяг, } \\
\text { тис. грн. }\end{array}$ & Частка, \% \\
\hline $\begin{array}{l}\text { Страхування від вогневих ризиків та } \\
\text { ризиків стихійних явищ }\end{array}$ & 201803 & 19,96 & 186327 & 29,67 \\
\hline Страхування майна & 182062 & 18,01 & 152218 & 24,24 \\
\hline Страхування залізничного транспорту & 117510 & 11,62 & 109286 & 17,40 \\
\hline $\begin{array}{l}\text { Страхування відповідальності перед } \\
\text { третіми особами }\end{array}$ & 111594 & 11,04 & 90295 & 14,38 \\
\hline $\begin{array}{l}\text { Страхування цивільної відповідальності } \\
\text { власників транспортних засобів } \\
\text { (за внутрішніми договорами) }\end{array}$ & 98136 & 9,71 & 5130 & 0,82 \\
\hline $\begin{array}{l}\text { Страхування цивільної відповідальності } \\
\text { власників транспортних засобів } \\
\text { (за міжнародними договорами) }\end{array}$ & 66996 & 6,63 & 22182 & 3,53 \\
\hline Страхування наземного транспорту & 63188 & 6,25 & 6940 & 1,10 \\
\hline Медичне страхування & 53664 & 5,31 & 2363 & 0,38 \\
\hline Страхування вантажів та багажу & 45507 & 4,50 & 16751 & 2,67 \\
\hline Інші види & 70399 & 6,96 & 36591 & 5,83 \\
\hline Сума & 1010859 & 100 & 628083 & 100 \\
\hline
\end{tabular}


Таблиця 4

Запас платоспроможності ПрАТ «УАСК АСКА» за 2018-2020 роки

\begin{tabular}{|l|c|c|c|c|c|c|c|}
\hline \multirow{2}{*}{ Показник } & \multicolumn{3}{c|}{ Значення } & \multicolumn{2}{c|}{$\begin{array}{c}\text { Абсолютна } \\
\text { зміна }\end{array}$} & \multicolumn{2}{c|}{$\begin{array}{c}\text { Темп приросту } \\
\text { (спаду), \% }\end{array}$} \\
\cline { 2 - 9 } & $\mathbf{2 0 1 8}$ & $\mathbf{2 0 1 9}$ & $\mathbf{2 0 2 0}$ & $\mathbf{2 0 1 9}$ & $\mathbf{2 0 2 0}$ & $\mathbf{2 0 1 9}$ & $\mathbf{2 0 2 0}$ \\
\hline $\begin{array}{l}\text { Фактичний запас } \\
\text { платоспроможності }\end{array}$ & 175147 & 188575 & 193255 & 13428 & 4680 & 7,67 & 2,48 \\
\hline $\begin{array}{l}\text { Нормативний запас } \\
\text { платоспроможності }\end{array}$ & 70063 & 79984 & 123617 & 9921 & 43633 & 14,16 & 54,55 \\
\hline $\begin{array}{l}\text { Нормативний запас } \\
\text { платоспроможності }\end{array}$ & 20622 & 36326 & 56104 & 15704 & 19778 & 76,15 & 54,45 \\
\hline $\begin{array}{l}\text { Перевищення фрактичного } \\
\text { запасу платоспроможності } \\
\text { над нормативним }\end{array}$ & 105084 & 108591 & 69638 & 3507 & -38953 & 3,34 & $-35,87$ \\
\hline
\end{tabular}

Джерело: [2; 3]

хування. Майже в повному обсязі на перестрахування були передані ризики за такими видами, як: страхування вогневих ризиків та ризиків стихійних явищ, страхування майна, страхування залізничного транспорту та страхування відповідальності перед третіми особами. Саме на ці види страхових послуг припадає практично увесь перестрахований порторель. В компанії високий також показник перестрахування, який обумовлений страхуванням промислових об'єктів, страхова сума яких значно перевищує власне утримання страховика.

Таким чином, зважаючи на проведені дослідження, можна стверджувати, що перестрахувальний захист ПрАТ «УАСК АСКА» $€$ на достатньо високому рівні, проте негативним $€$ значне перевищення рівня перестрахування страховика над тим, що спостерігається на страховому ринку в цілому [4; 5].

Загальна оцінка страхової діяльності компанії хоч і покращилась за останній період, проте фрінансовий стан її $€$ нестабільним, оскільки показники знаходяться на рівні нижчому за середній. Розрахунок запасу платоспроможності компанії представлено в табл. 4.

Як бачимо, за аналізовані періоди відбувалося зростання як фрактичного, так і нормативного запасів платоспроможності компанії. ПрАТ «УАСК АСКА» повністю дотримувалось умов забезпечення платоспроможності, про що свідчить перевищення фрактичного запасу платоспроможності над нормативним. Також слід розуміти, що фрактичними показниками ефрективності діяльності будь-якої страхової компанії є її фрінансові результати (див. рис. 4).

3 рис. 5 видно, що протягом аналізованих років компанія нарощувала обсяги валових премій. У 2020 році страховик підписав на $55,24 \%$ премій більше, ніж у попередньому періоді. Проте, чисті страхові премії компанії зростали повільнішими темпами. Це свідчить про значний обсяг перестрахувальних операцій здійснюваних страховиком. Валовий прибуток страховика зростав на 29,51\% у 2019 році та 40,33\% у 2018 році. Це свідчить про покращення ефрективності страхової діяльності. Проте, не зважаючи на зростання валового прибутку страховика, протягом останніх років прибуток від операційної діяльності залишався на стабільному рівні. Основною причиною цього $€$ постійне зростання витрат на ведення страхової справи, які нівелюють ріст валового прибутку.

Стабільною тенденцією останніх років $\epsilon$ покращення результатів діяльності компанії за рахунок саме інвестиційних доходів. Протягом останніх років прибуток до оподаткування практично вдвічі перевищував фрінансовий результат від основної діяльності. Про ефективність діяльності ПрАТ «УАСК АСКА» свідчить те, що компанія протягом останніх років одержує позитивний фрінансовий результат. Однак, зменшення чистого прибутку у 2019 році стверджувало про необхідність оптимізації фрункціонування страховика. При оцінці ефективності діяльності компанії і подальшої оптимізації її рівня перестрахування доцільно розрахувати показники рентабельності страховика (див. табл. 5).

3 табл. 6 видно, що всі показники рентабельності страховика значно погіршилися у 2020 році і мають подальшу тенденцію до погіршення. Це свідчить про зменшення ефективності використання активів ПрАТ «УАСК АСКА», віддачі її капіталу, зниження ринкової привабливості в результаті зменшення рентабельності власного капіталу, а також погіршення безпосередньої ефективності ведення страхової діяльності. 


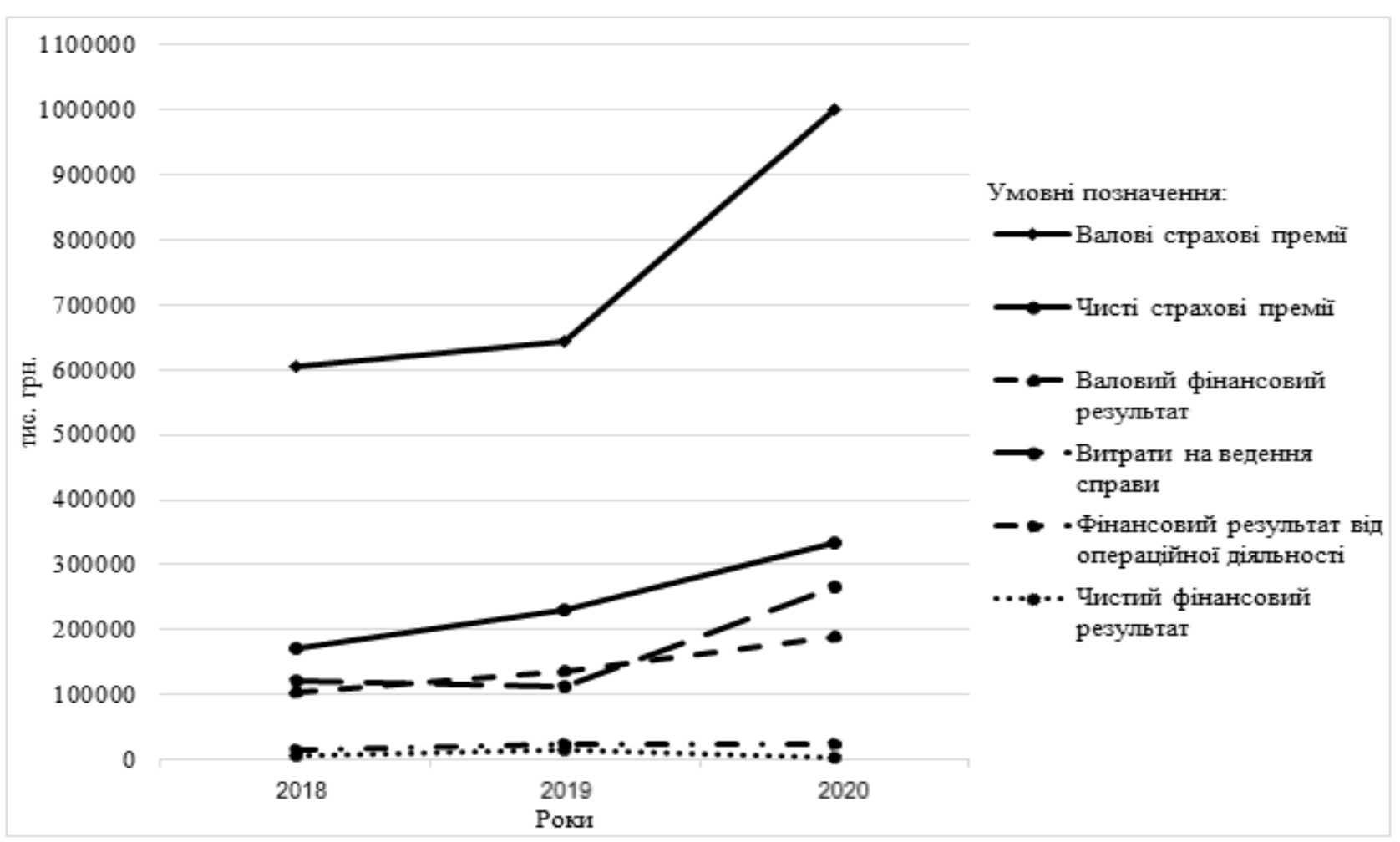

Рис. 4. Показники діяльності ПрАТ «УАСК АСКА» за 2018-2020 роки

Джерело: [2; 3]

Загалом стратегічний аналіз ПрАТ «УАСК АСКА» обов'язково має включати в собі стратегію і оцінку перестрахувального захисту компанії. Особливе місце займає розробка шляхів щодо удосконалення перестрахувального захисту страховика. У даному випадку перестрахування страхової компанії - це окремий фрінансовий механізм страхування, за допомогою якого страховики підтримують рівень своєї платоспроможності та виконують покладені на них зобов'язання [6, с. 38].

До позитивних наслідків перестрахування можна віднести зниження рівня ризику, який залишається на утриманні компанії та отри- мання комісійних винагород. До негативних належить недоотримання доходів від інвестиційної діяльності.

3 метою оптимізації рівня перестрахування на підставі дослідження праць широкого кола науковців можна сорормувати системнокомплексну економіко-математичну модель (1) - (7) [1; 6]:

$$
\begin{aligned}
& \text { Пч = Осп -Оп -Спсп + Окв +Опв + Оід - Опп , } \\
& \Pi_{4} \rightarrow \max \\
& \mathrm{O} \Pi=\mathrm{C} \Pi \times \mathrm{opt} P \Pi \\
& \text { Спсп }=\frac{O c п \times(1-o p t P п)}{O c \Pi_{0} \times\left(1-P \Pi_{0}\right)} \times C п c \Pi_{0}
\end{aligned}
$$

Таблиця 5

Показники рентабельності ПрАТ «УАСК АСКА» за 2018-2020 роки

\begin{tabular}{|l|c|c|c|c|c|c|c|}
\hline \multirow{2}{*}{\multicolumn{1}{|c|}{ Показник }} & \multicolumn{3}{c|}{ Значення, \% } & \multicolumn{2}{c|}{ Абсолютна зміна } & \multicolumn{2}{c|}{$\begin{array}{c}\text { Темп приросту } \\
\text { (спаду), \% }\end{array}$} \\
\cline { 2 - 9 } & $\mathbf{2 0 1 8}$ & $\mathbf{2 0 1 9}$ & $\mathbf{2 0 2 0}$ & $\mathbf{2 0 1 9}$ & $\mathbf{2 0 2 0}$ & $\mathbf{2 0 1 9}$ & $\mathbf{2 0 2 0}$ \\
\hline Рентабельність активів & 0,81 & 1,76 & 0,33 & 0,95 & $-1,43$ & 116,71 & $-81,11$ \\
\hline Рентабельність капіталу & 2,87 & 4,03 & 3,74 & 1,16 & $-0,29$ & 40,41 & $-7,30$ \\
\hline $\begin{array}{l}\text { Рентабельність } \\
\text { власного капіталу }\end{array}$ & 4,54 & 8,16 & 1,49 & 3,63 & $-6,67$ & 79,96 & $-81,71$ \\
\hline $\begin{array}{l}\text { Рентабельність } \\
\text { страхової діяльності }\end{array}$ & 10,04 & 13,39 & 7,06 & 3,34 & $-6,33$ & 33,30 & $-47,28$ \\
\hline Рентабельність продаж & 1,27 & 2,34 & 0,29 & 1,07 & $-2,05$ & 84,10 & $-87,66$ \\
\hline
\end{tabular}




$$
\begin{aligned}
& О \kappa в=\frac{O c \Pi \times o p t P \Pi}{C \Pi_{0} \times P \Pi_{0}} \times O \kappa B_{0} \\
& \text { Опв }=\frac{C \Pi}{C \Pi_{0}} \times O \Pi B_{0} \\
& \text { Oid }=\frac{O c{ } \times(1-o p t P \Pi)}{O c \Pi_{0} \times\left(1-P \Pi_{0}\right)} \times O i \partial_{0} \\
& \text { Опп }=(\text { Осп -Оп - Спсп +Окв-Опв +Оід }) \times 0,18 ; \\
& \text { Окв } \geq \sum_{i=1}^{n} \frac{\mathrm{OKB}_{i}}{n} ; 0 \leq \text { opt } \mathrm{P} \pi \leq 1
\end{aligned}
$$

де Пч - чистий прибуток страхової компанії; орtРп - оптимальний рівень перестрахування у страховій компанії; $Р \Pi_{0}-$ рівень перестрахування у попередньому періоді; Осп - прогнозований обсяг страхових премій; Осп - обсяг страхових премій у попередньому періоді; Оп - прогнозований обсяг перестрахованих премії; Спсп - обсяг перестрахованих премій у попередньому періоді; Спсп - прогнозована собівартість страхових послуг компанії; Спсп - собівартість страхових послуг компанії у попередньому періоді; Окв - прогнозований обсяг комісійних винагород; Окв - обсяг комісійних винагород у попередньому періоді; Окв них винагород у і-му періоді; Опв - прогнозований обсяг витрат на ведення страхової

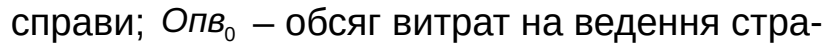
хової справи у попередньому періоді; Оід прогнозований обсяг інвестиційного доходу компанії; Оiд - обсяг інвестиційного доходу страхової компанії у попередньому періоді; Опп - обсяг податку на прибуток.

Для реалізації даної інтегрованої моделі використано програму MS Excel «Пошук рішення» на прикладі діяльності ПрАТ «УАСК АСКА». Результати проведеного моделювання представлено у табл. 6.
Відповідно до результатів моделювання, оптимальний рівень перестрахування для ПрАТ «УАСК АСКА» на останній звітний період складає 24,8\%. Зменшення обсягу перестрахованих премій матиме значний вплив на інші показники компанії. По-перше, це призведе до зростання обсягу чистих премій, а відповідно і збільшення ризиків, що залишатимуться на утриманні страховика. Наслідком цього буде збільшення чистих понесених збитків за страховими преміями. По-друге, у зв'язку зі зменшенням обсягу перестрахування, компанія отримає менший обсяг комісійних винагород від перестрахувальників. Окрім цього передбачається, що витрати на ведення справи компанії не повинні суттєво змінитися. По-третє, очікується, що відбудеться зростання інвестиційних доходів страховика у зв'язку зі збільшенням обсягу інвестиційних ресурсів. Як результат, компанія отримає значний фрінансовий результат до оподаткування, з якого сплатить податок на прибуток найбільший за останні роки. Не зважаючи на це варто очікувати значний обсяг чистого прибутку. Отже, для покращення фрінансових результатів компанії у подальшому рекомендується зменшити обсяг перестрахування.

Висновки. Здійснено аналіз і оцінку діяльності ПрАТ «УАСК АСКА» у розрізі визначення оптимального рівня перестрахування. Зокрема, визначено стратегічні альтернативи розвитку страховика та проведено аналіз страхової діяльності та оцінено фрінансовий стан у розрізі перестрахувального захисту. Розроблено окремі рекомендації щодо удосконалення і зміни рівня перестрахувального захисту компанії. У динаміці за останній період зростає обсяг перестрахування. Зважаючи на

\begin{tabular}{|c|c|c|c|c|c|c|c|}
\hline \multirow{2}{*}{ Показники } & \multicolumn{6}{|c|}{ Роки } & \multirow{2}{*}{ Opt } \\
\hline & 2015 & 2016 & 2017 & 2018 & 2019 & 2020 & \\
\hline Страхові премії & 614196 & 504855 & 809045 & 603748 & 644686 & 1000801 & 910944 \\
\hline Перестраховані премії & 304741 & 289125 & 606891 & 430974 & 414856 & 667928 & 225881 \\
\hline Собівартість страхових I & 138443 & 126200 & 70391 & 68146 & 94330 & 142725 & 293733 \\
\hline Комісійні винагороди & 13051 & 26779 & 47689 & 21320 & 11413 & 116853 & 39518 \\
\hline Витрати на ведення справи & 120621 & 120695 & 141738 & 122361 & 112718 & 267344 & 243340 \\
\hline Інвестиційний дохід & 11374 & 15836 & 20290 & 13313 & 13261 & 14153 & 29127 \\
\hline Податок на прибуток & 16575 & 12457 & 32640 & 19479 & 19508 & 29611 & 38994 \\
\hline Чистий прибуток & -21654 & -3570 & -59394 & 7660 & 15058 & 2885 & 177641 \\
\hline Рівень перестрахування & 0,4962 & 0,5727 & 0,7501 & 0,7138 & 0,6435 & 0,6674 & 0,2480 \\
\hline
\end{tabular}
такі результати, страховій компанії необхідно проаналізувати помилки в діяльності та при-

Результати реалізації моделі на основі програми MS Excel «Пошук рішення» для ПрАТ «УАСК АСКА» 
йняти еорективні управлінські рішення щодо розроблення подальших рішень щодо зміни перестрахувального захисту і відповідно до використаної інтегрованої економіко-матема- тичної моделі, страховику доцільно зменшити на перспективу свій рівень перестрахування, що дозволить даній страховій компанії суттєво покращити свої фрінансові результати.

\section{СПИСОК ВИКОРИСТАНИХ ДЖЕРЕЛ:}

1. Прокоф'єва О.В. Ринок перестрахування в період глобальної рецесії. Вісник Київського національного університету імені Тараса Шевченка. Економіка. 2016. № 3. С. 38-41. URL: http://nbuv.gov.ua/UJRN/VKNU_ Ekon_2016_3_8

2. Офріційний сайт страхової компанії ПрАТ «УАСК АСКА» (н.д.). URL: https://aska.ua/

3. Фінансова звітність страхової компанії ПрАТ «УАСК АСКА» (н.д.). URL: https://aska.ua/ua/about/financialstatements.html

4. Інформація про стан і розвиток страхового ринку України (н.д.). URL: https://www.nfp.gov.ua/ua/ Informatsiia-pro-stan-i-rozvytok-strakhovoho-rynku-Ukrainy.html

5. Інформація сайту фориншурер (н.д.). URL: https://forinsurer.com/

6. Шірінян Л.В. Фінансова надійність і фінансова стійкість страховиків. Актуальні проблеми економіки. 2007. № 9. С. 173-179.

\section{REFERENCES:}

1. Prokofieva O.V. (2016) Rynok perestrakhuvannia v period hlobalnoi retsesii [Reinsurance market during the global recession]. Visnyk Kyivskoho natsionalnoho universytetu imeni Tarasa Shevchenka. Ekonomika - Bulletin of the Taras Shevchenko National University of Kyiv. Economy, 3, 38-41. Retrieved from: http://nbuv.gov.ua/UJRN/ VKNU_Ekon_2016_3_8 (in Ukrainian)

2. Official site of the insurance company of PrJSC «UJSIC ASKA». Retrieved from: https://aska.ua/ (in Ukrainian)

3. Financial statements of the insurance company of PrJSC «UJSIC ASKA». Retrieved from: https://aska.ua/ua/ about/financial-statements.html (in Ukrainian)

4. Information on the state and development of the insurance market of Ukraine. Retrieved from: https://www.nfp.gov.ua/ua/Informatsiia-pro-stan-i-rozvytok-strakhovoho-rynku-Ukrainy.html (in Ukrainian)

5. Site information foreschurer. Retrieved from: https://forinsurer.com/ (in Ukrainian)

6. Shirinyan L.V. (2007) Finansova nadiinist i finansova stiikist strakhovykiv [Financial reliability and financial stability of insurers]. Aktualni problemy ekonomiky - Current issues of economics, 9, 173-179. (in Ukrainian) 